\title{
Public policies reflected on hospitalizations for ambulatory care sensitive conditions: an ecological study in Sergipe-Brazil, 2008-2017
}

Cátia Maria Justo ( $\nabla$ catia_justo@hotmail.com )

Univesidade Federal de Sergipe https://orcid.org/0000-0001-5417-0599

Kleyton de Andrade Bastos

Pos graduate Program in Health Sciences at Federal University of Sergipe

Fúlvio Borges Nedel

Universidade Federal de Santa Catarina Centro de Ciencias Biologicas

Research article

Keywords: Primary Health Care, Hospitalization, Health Indicators, Health Policies, Ecological study.

Posted Date: August 24th, 2020

DOI: https://doi.org/10.21203/rs.3.rs-59466/v1

License: (1) This work is licensed under a Creative Commons Attribution 4.0 International License.

Read Full License 


\section{Abstract}

Background: Hospitalization for Ambulatory Care Sensitive Conditions (HACSC) are an indicator of failure at this level of the health system. Since 2006, a series of actions have been taken in Brazil to promote Primary Health Care (PHC), a situation that has changed radically since 2014. To analyze the trend of the HACSC in Sergipe, in the period from 2008 to 2017.

Methods: Ecological time-trend analysis. The data were extracted from the hospital admission authorizations on Hospital Information System in Brazilian Unified Health System. It was classified according to the Brazilian List of HACSC. The rates were standardized by the indirect method.

Findings: There were 608,083 non-obstetric admissions and 125,497 HACSC (20.6\%), with an overall rate of 5.8 admissions per thousand inhabitants ( 5.7 male and 5.8 female). The trend described a U-curve, decreasing from 2008 to 2011, with little oscillation from 2011 to 2014, rising from 2014 to 2017. The rate was considerably higher in men over the age of 70 . Throughout the period, the most frequent causes were: gastroenteritis and complications (15.6\%), kidney and urinary tract infection (9.4\%), asthma (9.2\%), heart failure (8.8\%), cerebrovascular (8.1\%), and diabetes mellitus $(7.2 \%)$.

Conclusion: The indicator improved in the initial period of the study, following the introduction of public policies that strengthened PHC, and worsened as they were withdrawn or neglected.

\section{Background}

Primary Health Care (PHC) is a model for organizing citizens' first contact with health services, it was proposed in 1975 by the World Health Organization (WHO) as a Global Strategy for Health by Year 2000 (SPT-2000) and it strongly reiterated at the famous Alma-Ata Conference in 1978. PHC works with a generalist multi-professional team to offer integral and longitudinal care to all citizens of a defined territory, through individual and community actions. It is guided by principles of bond and coresponsibility between professionals and users, and the health team and the community, and should be resolute for the vast majority of health problems and coordinator of care in the different instances of health care 1. Substantial evidence has recognized PHC as the most effective, efficient, safe and equitable organizational model to the basis of health care2.

The Brazilian Constitution of 1988, the result of the country's fight for re-democratization, it was included a chapter for social security, which enunciates health as a right and created the Unified Health System (Sistema Único de Saúde - SUS) of universal and equitable access for health promotion, protection, and recovery, despite the system's underfunding3. After implementing SUS, the changes path of the PHC in Brazil was paved by Community Health Workers Program (Programa de Agentes Comunitários de Saúde PACS) and Family Health Program (Programa Saúde da Família - PSF), created at the end of 1993 as a strategy to change the Brazilian model of care. In 2006, when Brazil finally adopted a National Basic Care Policy (Política Nacional de Atenção Básica - PNAB), it became the primary organization for PHC, adopting the name of Family Health Strategy (Estratégia Saúde da Família - ESF)4. ESF is a national 
strategy, with financial incentives (until 2017) for its adoption by the municipality, which is voluntary and does not require complete populational coverage. Therefore, we have different coverage in the country and within municipalities.

Health management should be guided by quality information available to the manager and social control. Among the instruments for evaluating the effectiveness of PHC is the Hospitalizations for Ambulatory Care Sensitive Conditions (HACSC) indicator. Ambulatory Care Sensitive Conditions (ACSC) are health problems typically seen at the first level of the health system and whose evolution will require hospitalization of the patient in the absence of effective and timely intervention. Examples are the prevention of the incidence of diseases, such as in the use of vaccines and syphilis treatment in pregnant women; the treatment of acute episodes, such as in the case of dehydration and bacterial pneumonia; and the control of prevalent chronic conditions such as diabetes mellitus and systemic arterial hypertension, thus avoiding or delaying hospitalizations for renal failure, peripheral arterial disease, diabetic foot, acute myocardial infarction or strokes5,6.

The use of the indicator is based on the premise that hospitalization at the moment it occurs, is necessary for the patient. This need results from failures in the first level of the health system5,6. In 2008, the Ministry of Health published the Brazilian List of Sensitive Conditions for Primary Health Care, instituted by the Ministry of Health's Ordinance No. 221 of April 17, 20087. The list, composed of 19 groups of causes, and widely accepted by the academic community, facilitates the performance and provides greater consistency to indirect evaluation studies of the effectiveness of PHC in Brazil.

Brazilian studies have shown the expansion of the ESF, associated with a significant reduction in HACSC. From 1998 to 2006 there was a 17\% reduction in the HACSC rate, while ESF teams throughout Brazil increased from 3062 in 1998 to 26,364 in 20068. In Sergipe, the decrease of HACSC rates is in part due to the More Doctors Program (PMM), an emergency physician allocation program for PHC in hard-to-reach areas, supported in large part by the Cuban Government's collaboration by sending doctors 9 . The Brazilian Northeast, where this study is performed, has the lowest Human Development and life expectancy rates, the worst infrastructure indicators (basic sanitation such as sewage and piped water), poor schooling, and the highest child mortality rates, compared to other Brazilian regions10.

From 2006, a set of public policies were implemented to better organize the SUS, guided by a logic centered on universal, integral, longitudinal, and attention coordinative PHC. Since 2013, however, Brazil has been experiencing a political, legal, and economic instability scenario and it has discontinued social, cultural, and environmental policies, as measures to confront the economic crisis, the so-called "austericide"11. In the political field after the impeachment of President Dilma Rousseff in 2016, we culminated with the unbelievable Bolsonaro government12. In public health, we saw the reduction of vaccination coverage by half, the increase in infant and child mortality from 2016 , and maternal mortality in 2018, as well as the measles epidemic in 201913. Therefore, we should expect that the political and institutional weaknesses, the cut in resources, and the consequent weakening of SUS management that led to the worsening of the aforementioned indicators, will also compromise the effectiveness of PHC. 
No studies were found that evaluate the effectiveness of PHC in this period in Sergipe with this focus. The objective of this study is to contribute filling this gap by analyzing the evolution of HACSC rates in Sergipe in the years 2008 to 2017, a period that encompasses investment in PHC, political instability, and finally the implementation of fiscal austerity policies.

\section{Methods}

The state of Sergipe, the smallest in territorial extension in Brazil, with 21,926,908 km2, is part of the Brazilian semiarid region, which has, among other characteristics, the daily percentage of water deficit equal to or greater than $60 \%$. The Human Development Index was 0.665 in 2010 . The population of Sergipe, in its 75 municipalities, in 2010 census had 2,068,017 inhabitants, of which 51.4\% were women and $73.5 \%$ lived in an urban area, according to Brazilian Institute of Geography and Statistics (Instituto Brasileiro de Geografia e Estatística - IBGE) in 2010. PACS and PSF in Sergipe were created in 1998 and ESF began in 2007, a year in which 127 family health teams were established, covering $87 \%$ of the population13, and remained at these proportions until the end of the study in 2017.

An ecological study was conducted using the Databases from the SUS Hospital Information System (BDHIS/SUS). The so called "reduced files" of Hospitalization Admission Authorization (AlH) were used, from which the main diagnosis of the hospitalization, date of admission, gender, age, and city of residence were obtained. These "AlH files" are made available in separate files by State and month of admission billing (called "month of competence"), which is the same month of hospitalization in most cases. But the AlH can be billed later, which can cause both inclusion of cases occurring a few months before the period of interest and loss of cases in the last months of the selected period that were billed later. To avoid these problems, the data files of the State of Sergipe were read from January 2008 to July 2018 , afterward, only those cases whose hospitalization occurred from $01 / 01 / 2008$ to 31/12/2017 were selected. Only cases of citizens residing in Sergipe were also selected. Finally, hospitalizations for obstetric procedures to treat non-morbid conditions such as childbirth and abortion were excluded. Hospitalizations were classified as ACSC according to the Brazilian List of Ambulatory Care Sensitive Conditions, composed of a wide range of 19 groups of causes.

The crude rates of HACSC per year were calculated, then standardized by sex and age by the indirect method (calculation of the Standardized Hospitalization Ratio - SHR), taking 2014 as the reference year, since it is the lowest crude rate. Thus, the meaning of every presented SHR is how much the rate that year was higher than in 2014, adjusted for gender and age - leaving 1 to the value presented and multiplying by 100 , obtaining the value in proportion, i.e., an SHR $=1.241$ means a HACSC rate $24.1 \%$ higher than that observed in 2014 , the lowest rate of the period.

The standardized rates trend in the period was analyzed by simple linear regression, despite a positive autocorrelation (Durbin-Watson test $=0.6 ; \mathrm{p}<0.001$ ). Given the observed distribution, two explanatory models of the distribution of SHR as a function of time were tested: one considering the year plus a quadratic term of the year $\left(\mathrm{SHR}=\right.$ intercept + year + year $\left.{ }^{2}\right)$ and another dividing the period into three 
(2008-2010, 2011-2014, 2015-2017), analyzed as a categorical variable. Considering the few observations and the percentile distribution of the residues, the models were considered adequate. Data capture on the internet, reading of files, classification of hospitalizations, analysis, and graphical presentation were performed using the $\mathrm{R}$ statistical software. For data capture and reading, the microdatasus 14 package was used and the classification was made by the csapAlH15 package. Compressed files (DATASUS .dbc format) are read by the read.dbc16 package. Since AlH files are publicly accessible without locks (with access restrictions from outside Brazil since 2017), the process we have performed can be reproduced in $\mathrm{R}$ by running the command script file, which may be requested from authors.

This research is part of the Ph.D. project: Hospitalizations due to Ambulatory Care Sensitive Conditions in Sergipe-Brazil follows the ethical recommendations of the National Health Council contained in Resolution No. 466 of December 12, 2012, submitted to the Committee of Ethics and Research of the Federal University of Sergipe and approved under Ruling No. 2.232.566 and CAAE: 69111717.5.0000.5546.

\section{Results}

During this period of ten years analyzed, there were 608,353 hospitalizations, excluding obstetric hospitalizations, well distributed between genders (49\% males, $51 \%$ females). In the period, there were 125,497 cases of HACSC, representing a global rate of 5.8 HACSC per thousand inhabitants (Table 1). The rate distribution shows a curve in U, falling until 2011, stabilizing with some oscillation until 2014, when it reaches the lowest rate, and then rising consistently until the end of the period of study, with a standardized rate in 2017 only $4 \%$ lower than in 2008 . In the period, $20.6 \%$ of admissions were due to ACSC, ranging from $18.8 \%$ in 2011 to $24.1 \%$ in 2017 . The model with year + year $^{2}$ as predictors explained $92 \%$ of the variability observed in standardized rates (Adjusted $\mathrm{R}^{2}=0.917 ; \mathrm{p}<0.001$ ), with high statistical significance $(p<0.001)$ in both variables. The model with the year in three categories $(2008-2010,2011$ $2014,2015-2017$ ) explained $60 \%$ of the variability of the standardized rates (adjusted $R^{2}=0.597 ; p=$ $0.02)$, with the middle period significantly different from the initial period $(p=0.006)$, but without statistical difference with the final period $(p=0.16)$, showing the improvement of the rates at the beginning of the period and a subsequent worsening, returning to the initial situation (Figure 1). The proportion of ACSC among hospitalizations was higher in 2017 than in 2008.

The crude rate of HACSC in the period was 5.7 cases per thousand inhabitants in males and 5.8 in females, although the standard rate by age group is slightly higher in men. The proportion of hospitalizations is similar between genders: in males, $20 \%$ of hospitalizations were due to ACSC, and $21 \%$ in females. The women presented ages from 0 to 109 years, mean of 40.4, a standard deviation of 30.0, and a median of 42 years. Men were aged from 0 to 117 years, mean 39.4, standard deviation 30.8, and median 44 years. Just under a quarter (23\%) of hospitalizations for ACSC are under five years old, and $15 \%$ of children under two years old. The median age was 42 years and the 75 th percentile was 67 years old. The median and mean age is higher in 2017, while decreasing the coefficient of variation, reflecting 
population aging. From 70 years of age, the rate is considerably higher in men (Figure 2). The elderly are the age group that most benefited between 2008 and 2014, but in 2017 they already had rates close to those at the beginning of the period. Children had little improvement between 2008 and 2014 and the rates in 2017 were higher than at the beginning of the period (Figure 3).

Throughout the period, the most common causes of ACSC were: gastroenteritis and complications $(15.6 \%)$, kidney and urinary tract infection (9.4\%), asthma (9.2\%), heart failure (8.8\%), cerebrovascular (8.1\%), diabetes mellitus (7.2\%), bacterial pneumonia (6.7\%), chronic obstructive pulmonary disease (6.1\%), systemic arterial hypertension (5.4\%), and skin and subcutaneous infection (5.2\%). In the age group from 0 to 14 years, gastroenteritis significantly decreased from 2008 to 2014, decelerating but still decreasing in 2017, from $50.0 \%$ in 2008 to $25.9 \%$ in 2014 and $22.2 \%$ in 2017). Asthma was the second cause in this range, which continued to increase slightly from $17.2 \%$ in 2008 to $20.0 \%$ in 2014 and $22.5 \%$ in 2017. Bacterial pneumonia was the third most frequent cause in this range, with little variation $(8.4 \%$ in $2008,9 \%$ in 2014 , and $9 \%$ in 2017).

In the age group of 15 to 49 years, gastroenteritis followed a declining trend ( $25 \%$ in $2008,14 \%$ in 2014 , and $11 \%$ in 2017). Urinary tract infection was the second most common cause in 2008 and 2014, and the first in 2017, in this age group (15.7\% in 2008, 14.2\% in 2014 and $16.4 \%$ in 2017). In this range, attention is drawn to the skin and subcutaneous tissue infection, which rises from $1.6 \%$ in 2008 to $7.8 \%$ in 2014 and $10.6 \%$ in 2017.

In the age group of 50 or more years, heart failure is the most frequent cause, but reducing from $17.8 \%$ in 2008 , to $14.8 \%$ in 2014 and $13.9 \%$ in 2017 . On the other hand, Cerebrovascular increased from $11.7 \%$ in 2008 , to $16.1 \%$ in 2014 and $17.2 \%$ in 2017, and was the most frequent cause. Diabetes Mellitus is the third most common cause in this age group and also increased in the period, ranging from $10.9 \%$ in 2008 to $12.1 \%$ in 2014 and $13.4 \%$ in 2017 (Figure 5).

\section{Discussion}

The ESF has been proposed as a priority model for organizing PHC in several aspects, especially in improving accessibility and reducing inequities in less empowered groups of the population 17,18 . Several studies have found an inverse association between HACSC and ESF coverage19,20. However, in the period studied, ESF coverage in Sergipe remained above $80 \%$, with little variation, suggesting that in this period the effectiveness of PHC can be better assessed by other aspects than ESF coverage. In other words, the changes observed in the period are not due to a change in the supply of the service in terms of population coverage.

In the initial phase of the study, from 2008 to 2014, we observed a decrease in HCASC in Sergipe, which corroborates studies of similar periods in other places such as Goiás (Mid-West region of Brazil) from 2005 to 2015, Pernambuco (Northeast region) from 2008 to 2012 and Espírito Santo (Southeast region) from 2000 to 201421-23. Our research showed a U-curve over time, starting in 2008 with a continued decrease in the HCASC rate until 2011, followed by a stabilization until 2014, the year in which it reached 
a lower value. From then on, the indicator worsened, with a sharp increase in rates, which, at the end of the period, are similar to the beginning, showing a worsening of the advances achieved. The worsening occurs in all age groups, particularly among children, who have the HCASC rates in 2017 higher than in 2008. Statistical analysis showed that the values found at the end of the period are significantly different from the beginning, indicating that the behavior observed is not the result of random variation. The analysis also shows the aptness of the indicator to describe the outcome of health policies, which is consistent with the conceptual methodological framework that presents it with an indicator of the first level of the health system in all its scope, and not only of the care provided by the health team5,6.

The public policies that preceded and contributed to the performance of the indicator throughout the study period began with the publication of the 2006 PNAB, which marks the transition from PSF to ESF status. Integrative and Complementary Health Practices (also called "Alternatives") and the National Health Promotion Policy were also important milestones that year. In 2007, the Health at School Programme was created, and in 2008 the Family Health Support Centre (Núcleo de Apoio à Saúde da Família - NASF) was created. In 2011, the second edition of the PNAB, creation of the National Program for Improving Access and Quality of Basic Care (Programa Nacional de Melhoria do Acesso e da Qualidade da Atenção Básica - PMAQ) and creation of the Programs: Requalification of Basic Health Units; Better at Home; Academy of Health; of the teams of Clinic in the Street; of Telehealth Brazil Networks (Telessaúde Brasil Redes); and the review of the National Policy on Food and Nutrition. In 2012, there was the creation of the Basic Care Professional Valuation Program (Programa de Valorização do Profissional da Atenção Básica - PROVAB) and, in 2013, the More Doctors Program (Programa Mais Médicos - PMM) and the substitution of the Basic Care Information System by the e-SUS Basic Care and the Basic Care Health Information System (Sistema de Informação em Saúde da Atenção Básica SISAB).

This entire set of federal government policies has invested in improving the structure and health process of care, and expanding the accessibility, resulting in better effectiveness of PHC. However, as of 2014, the Brazilian economic crisis had repercussions in the rate of unemployment and increased social inequality, financial cuts, and social instability24, and the indicator began to assume the upward slope of the curve. In this regard, the approval of the Constitutional Amendment 95/2016 that establishes a spending cap in the next 20 consecutive years, along with environmental and educational policies will compromise the sustainability of the SUS and its constitutional premise of universal coverage and other attributes of the PHC24,25. In 2017, there was the third edition of the PNAB, with major setbacks and reformulation in its political orientation, and withdrawal of financial incentives to the ESF, which is why it suffered severe criticism from the Brazilian scientific community25,26.

The most frequent groups of causes in children up to 14 years old were gastroenteritis, asthma, bacterial pneumonia, and ear, nose, and throat infection. There was a significant decrease in gastroenteritis and complications, ranging from $50 \%$ of the HCASC in 2008 to $22 \%$ in 2017; asthma and pneumonia remained stable in the period. These causes were the same as those found in a study in Minas Gerais, Southeastern Brazil, for children and teenagers27. 
A study conducted in Sergipe from 2002 to 2012 on hospital admissions in teenagers showed a 143.1\% reduction in HCASC28. In the population of 50 or more years, the most frequent causes were heart failure, cerebrovascular diseases, diabetes mellitus, systemic arterial hypertension, nutritional deficiencies, and angina. A study conducted in Paraná, Southern Brazil, in the range of 60-74 years, presented similar results20. The improvement observed in the indicator before the most pronounced political changes from 2014 onwards was mainly due to more effective attention to the population over 50 years of age. It is notable that even among the very elderly, rates improved a lot, and then worsened. These results show that the exclusion of the elderly in studies that address the HCASC can be a mistake, since it was shown that it responds to the political actions driving the PHC. Thus, we should continue analyzing the indicator with all age groups - consistent with the principles of universality, equity, and integrality of PHC.

This study has its limitations, most dependent on the quality of information, as it uses secondary data, and the fact that SUS, despite being an universal system, has not total coverage of the hospital admissions. So, it is important to emphasize that about $88 \%$ of hospital admissions in Brazil are through SUS29. Nevertheless, the SIH-SUS has shown high reliability for the study of HACSC30.

\section{Conclusion}

The investment in PHC from 2006 was followed by the improvement of its effectiveness, measured by the HACSC rates. The changes in the country's political direction from 2014 onwards were accompanied by the worsening of the effectiveness of PHC in the state of Sergipe, in both genders and all age groups, returning to the levels observed at the beginning of the decade. The improvement in the indicator following the implementation of policies to strengthen PHC and its worsening in response to the country's political and economic crisis demonstrates the damage to Sergipe people's health caused by policies to withdraw social rights and diminish the state, concerning the most common health problems. This study reports us to the need for a national study to evaluate the effects of national political changes on the whole Brazil, as well as its Regions and States.

\section{Abbreviations}

ACSC - Ambulatory Care Sensitive Conditions

AlH - Hospitalization Admission Authorization (Autorização de Internação Hospitalar)

ESF- Family Health Strategy (Estratégia Saúde da Família)

HACSC - Hospitalization for Ambulatory Care Sensitive Conditions

IBGE - Brazilian Institute of Geography and Statistics (Instituto Brasileiro de Geografia e Estatística)

PACS - Community Health Workers Program (Programa de Agentes Comunitários de Saúde)

PHC - Primary health care 
PMM - More Doctors Program (Programa Mais Médicos)

PNAB - National Basic Care Policy (Política Nacional de Atenção Básica)

PSF - Family Health Program (Programa Saúde da Família)

SHR - Standardized Hospitalization Ratio

SUS - Unified Health System (Sistema Único de Saúde)

WHO - World Health Organization

\section{Declarations}

\section{Etthic aproval}

This research is part of the Ph.D. project: Hospitalizations due to Ambulatory Care Sensitive Conditions in Sergipe-Brazil follows the ethical recommendations of the National Health Council contained in Resolution $N^{\circ} 466$ of December 12, 2012, submitted to the Committee of Ethics and Research of the Federal University of Sergipe and approved under Ruling No 2.232 .566 and CAAE: 69111717.5 .0000 .5546 .

\section{Limitations}

This study has its limitations, most dependent on the quality of information, as it uses secondary data, and the fact that SUS, despite being an universal system, has not total coverage of the hospital admissions.

\section{Consent for publication}

All authors agree with the decision to submit the article.

\section{Avalilability of data and materials}

The data described in this Data note can be freely and openly accessed on ftp.datasus.gov.br/dissemin/publicos/SIHSUS/200801_/Dados/.

Please see table 1 and references for details nad links to the data.

\section{Competing Interests}

The authors declare that there is no relationships, conditions or circumstances that present a conflict of interest in the research.

\section{Funding}


The authors declare that there is o source of funding.

\section{Authors contributions}

JCM - Collaborated in the design of the project, writing of the article, analysis and interpretation of data, is responsible for all aspects of the work and in ensuring the accuracy and integrity of the entire work.

BKA - Collaboration: Collaborated in the design of the project, in the critical review and final approval of the version to be published.and in ensuring the accuracy and integrity of the entire work.

NFB - Collaboration: Collaborated in the design of the project, in the analysis and interpretation of data, critical review and relevant intellectual content and in ensuring the accuracy and integrity of the entire work.

"all authors have read and approved the manuscript"

\section{Acknowledgments}

The authors thank the opportunity for the Postgraduate Program in Health Sciences at the Federal University of Sergipe and the Study group on Epidemiology and Community Health at the Department of Public Health, Federal University of Santa Catarina.

\section{Data description}

\begin{tabular}{|c|c|c|c|}
\hline Label & $\begin{array}{l}\text { Name of data } \\
\text { file }\end{array}$ & $\begin{array}{l}\text { file types } \\
\text { (file } \\
\text { extension) }\end{array}$ & Data repository \\
\hline $\begin{array}{l}\text { RDSE0801, } \\
\ldots, \\
\text { RDSE1806 }\end{array}$ & $\begin{array}{l}\text { RDSE0801.dbc, } \\
\text {..., } \\
\text { RDSE1806.dbc }\end{array}$ & $\begin{array}{l}\text { DATASUS } \\
\text { compressed } \\
\text { file }(. d b c)\end{array}$ & ftp.datasus.gov.br/dissemin/publicos/SIHSUS/200801_/Dados/ \\
\hline População & popSE.xlsx & $\begin{array}{l}\text { MS Excel } \\
\text { file (.xlsx) }\end{array}$ & $\begin{array}{l}\text { Tabulated from } \\
\text { http://tabnet.datasus.gov.br/cgi/deftohtm.exe? } \\
\text { ibge/cnv/projpopuF.deF }\end{array}$ \\
\hline
\end{tabular}

\section{References}

1. Giovanella L, Mendonça MHM de, Buss PM, Fleury S, Gadelha CAG, Galvão LC, et al. e Alma-Ata a Astana, Atenção primária à saúde e sistemas universais de saúde: compromisso indissociável e direito humano fundamental. Cad Saúde Pública. 2019; 35 (3):e00012219. 
2. Macinko J, MendonçaCS. Estratégia Saúde da Família, um fore modelo de Atenção Primá um forte moria à Saúde que traz resultados. Saúde em Debate. 2018; 42(spe1):18-37.

3. Castro Mc, Massuda A, Almeida G, Menezes-Filho NA, Andrade MV, de Souza Noron ha KVM, et al. Brazil's unified health system: the first 30 years and prospects for the future. Lancet. 2019; 394(10195): 345-56.

4. Brasil. Ministério da Saúde. Secretaria de Atenção Básica. Política Nacional de Atenção Básica. Série Pactos Pela Saúde. 2006; 5 (5): 60.

5. Nedel FB, Facchini LA, Bastos JL, Martín M. Conceptual and methodological aspects in the study of hospitalizations for ambulatory care sensitive conditions. Cien Saude Colet. 2011; 16(Supl 1): 114554.

6. Ansari Z. The concept and usefulness of ambulatory care sensitive conditions as indicators of quality and access to primary health care. Aust J Prim Heal. 2007; 13 (3): 91-110.

7. Brasil. Ministério da Saúde. Secretaria de Atenção à Saúde. Portaria nº 221, de 17 de abril de 2008. Diário Oficial da União. Ministério da Saúde. 2008; p.70.

8. Alfradique ME, Bonolo P de F, Dourado I, Lima-Costa MF, Macinko J, Mendonça CS, et al. Internações por condições sensíveis à atenção primária: a construção da lista brasileira como ferramenta para medir o desempenho do sistema de saúde (Projeto ICSAP - Brasil). Cad Saúde Pública. 2009; 25 (6): 1337-49.

9. De Paula JB, Westphal MF. Sistemas de saúde, cooperação horizontal e o programa Mais Médicos no Brasil. Rev Bras em Promoção da Saúde. 2018;31(4):1-9.

10. Facchini LA, Piccini RX, Tomasi E, Silveira DS, Siqueira FV, Rodrigues MA. Desempenho do PSF no Sul e no Nordeste do Brasil: avaliação institucional e epidemiológica da Atenção Básica à Saúde. Cien Saude Colet. 2006;11(3):669-81.

11. Vieira FS, Santos IS, Ocké-Reis C, Rodrigues PH de A. Políticas sociais e austeridade fiscal. 2018. 64 p.

12. Doniec K, Dall'Alba R, King L. Brazil's health catastrophe in the making. Lancet. 2018; 392 (10149): 731-2.

13. Giovanella Ligia; Escorel LS; Mendonça MAM. Estudos de caso sobre implementação da Estratégia Saúde da Família em quatro grandes centros urbanos. Fundação Oswaldo Cruz. Relatório Final. 2009.

14. Saldanha R de F, Bastos RR, Barcellos C. Microdatasus: pacote para download e pré-processamento de microdados do Departamento de Informática do SUS (DATASUS). Cad Saúde Pública. 2019; 
35(9): e00032419.

15. Nedel FB. Pacote csapAlH: a Lista Brasileira de Internações por Condições Sen síveis à Atenção Primária no programa R. Epidemiol e Serviços Saúde. 2019; 28 (2): e2019084.

16. Petruzalek D. read.dbc: um pacote para importação de dados do datasus na linguagem R. J Heal Inf. 2016; 8(Supl.1): 601-5.

17. Facchini LA, Tomasi E, Dilélio AS. Qualidade da Atenção Primária à Saúde no Brasil: avanços, desafios e perspectivas. Saúde em Debate. 2018; 42 (spe 1): 208-23.

18. Afonso MPD, Shimizu HE, Merchan-Hamann E, Ramalho WM, Afonso T. Association between hospitalisation for ambulatory care-sensitive conditions and primary health care physician specialisation: A cross-sectional ecological study in Curitiba (Brazil). BMJ Open. 2017;7: e015322.

19. Ceccon RF, Meneghel SN, Viecili PRN. Internações por condições sensíveis à atenção primária e ampliação da Saúde da Família no Brasil: um estudo ecológico. Rev Bras Epidemiol. 2014; 17(4): 968-77.

20. Previato GF, Nogueira IS, Acorsi CRL, Baldissera VDA, Mathias TA de F. Diminuição de internações por condições sensíveis à atenção primária em idosos no estado do Paraná. Espaço para a Saúde Rev Saúde Pública do Paraná. 2017; 18(2): 15-24.

21. Maia LG, Silva LA da, Guimarães RA, Pelazza BB. Internações por condições sensíveis à atenção primária: um estudo ecológico. Rev Saude Pública. 2019; 53(2): 1-11.

22. Mendonça $S$ de $S$, Albuquerque $E C$ de. Perfil das internações por condições sensíveis à atenção primária em Pernambuco, 2008 a 2012. Epidemiol e Serviços Saúde. 2014; 23 (3): 463-74.

23. Pazó RG, Frauches DDO, Molina MDCB, Cade NV. Panorama das internações por condições sensíveis à atenção primária no Espírito Santo, Brasil, 2000 a 2014. Rev Bras Med Família e Comunidade. 2017; 12(39): 1-12.

24. Souza PHGF de, Medeiros M. A concentração de renda no topo no Brasil, 2006-2014. One Pager Portuguese. International Policy Centre for Inclusive Growth. 2017.

25. Paes-Sousa R, Rasella D, Carepa-Sousa J. Política econômica e saúde pública: equilíbrio fiscal e bem-estar da população. Saúde em Debate. 2018;42(spe3):172-82.

26. Brasil. Ministério da Saúde. Portaria n² 2.436, de 21 de setembro de 2017. Aprova a Política Nacional de Atenção Básica ( PNAB 2017), estabelecendo a revisão de diretrizes para a organização da atenção básica, no âmbito do sistema único de saúde (SUS). Diário Oficial da União. 22 Set 2017. 
27. Santos LA, De Oliveira VB, Caldeira AP. Hospitalizations for conditions susceptible to primary care among children and adolescents in Minas Gerais, Brazil, 1999-2007. Rev Bras Saúde Matern Infant. 2016;16(2):169-78.

28. Guimarães MN, Oliveira ER BA. Internações Hospitalares de Adolescentes em Sergipe, de 2002 a 2012. Rev Pau Pediatr. 2020;38.

29. Dutilh-Novaes HM. Internações no Sistema de Serviços Hospitalares, SUS e não SUS: Brasil, 2006. Rev Bras Epidemiol 2011;14(3):411-22.

30. Abaid R, Nedel F, Alcayaga E. Ambulatory care sensitive conditions: diagnostic reliability in southern Brazil. Journal of Epidemiology and Infection Control. 2014; 4(3):208-14.

\section{Figures}

\section{TEN MOST FREQUENT CAUSES OF HACSC IN SERGIPE FROM 2008 TO 2017}

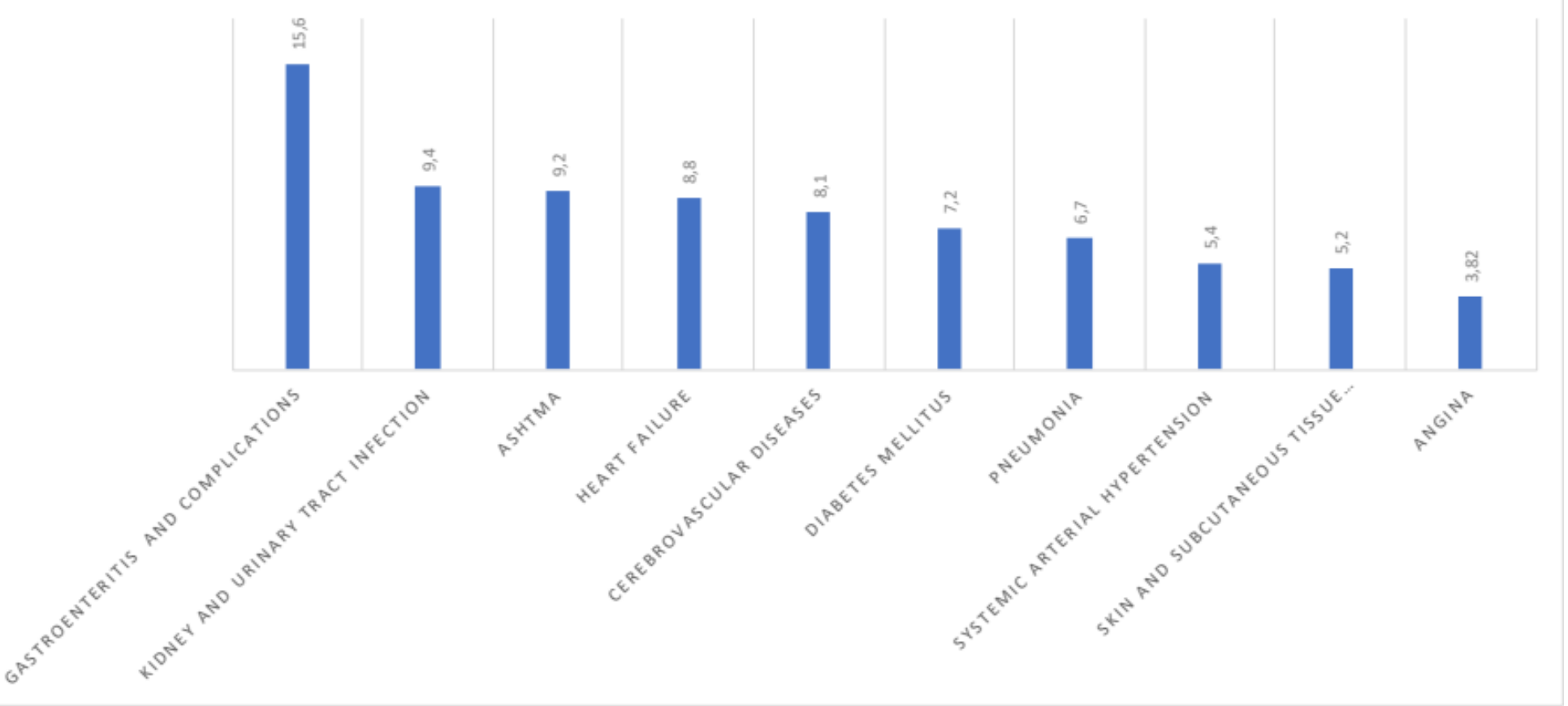

\section{Figure 1}

HACSC (Standardized Hospitalization Ratio - SHR), by year and gender in Sergipe, 2008-2017. 


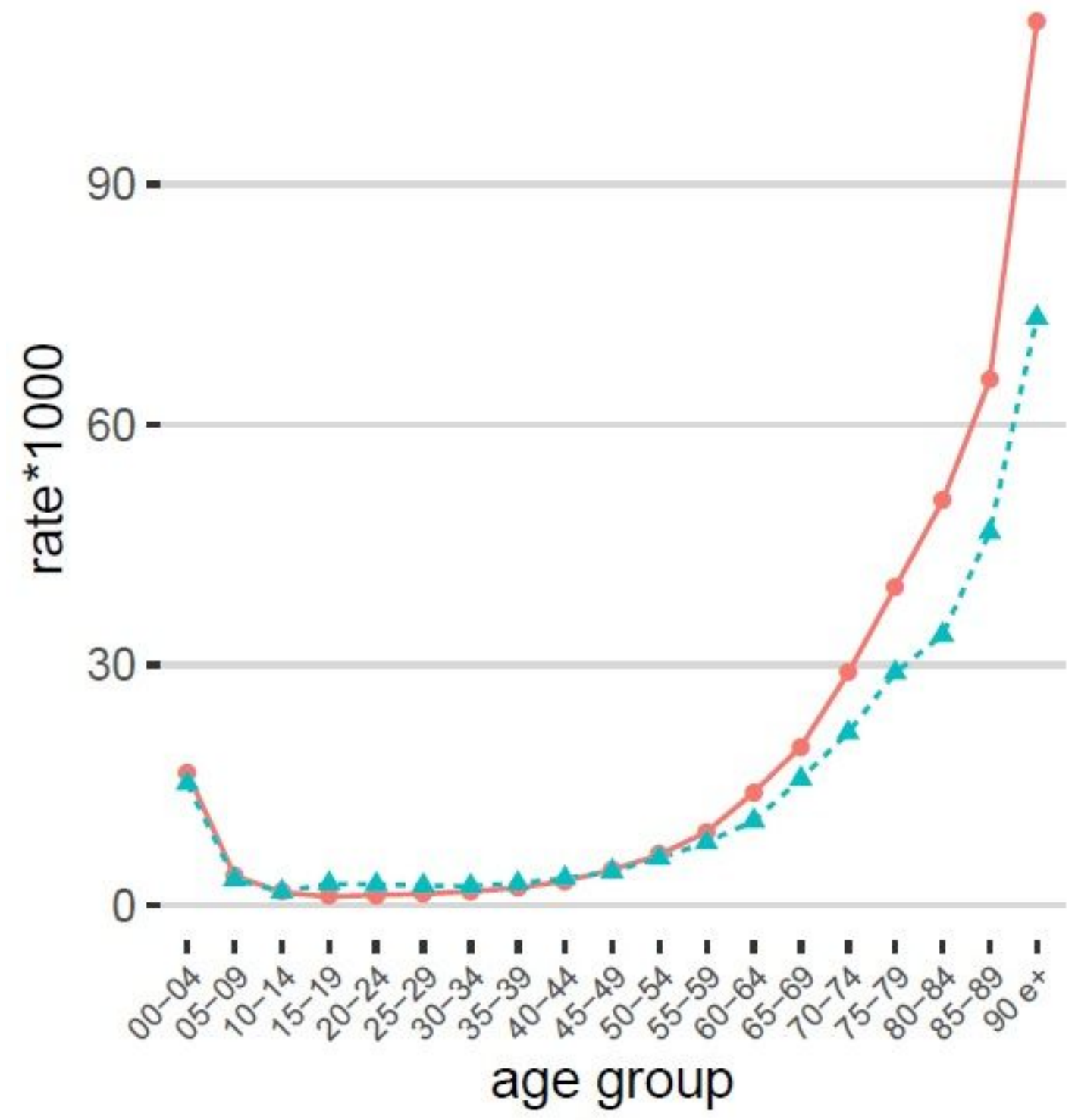

\section{gender $\multimap$ masc $\leadsto$ fem}

\section{Figure 2}

Hospitalizations for ambulatory care sensitive conditions (Rate by thousand inhab) by age group and gender in Sergipe 2008-2017. 


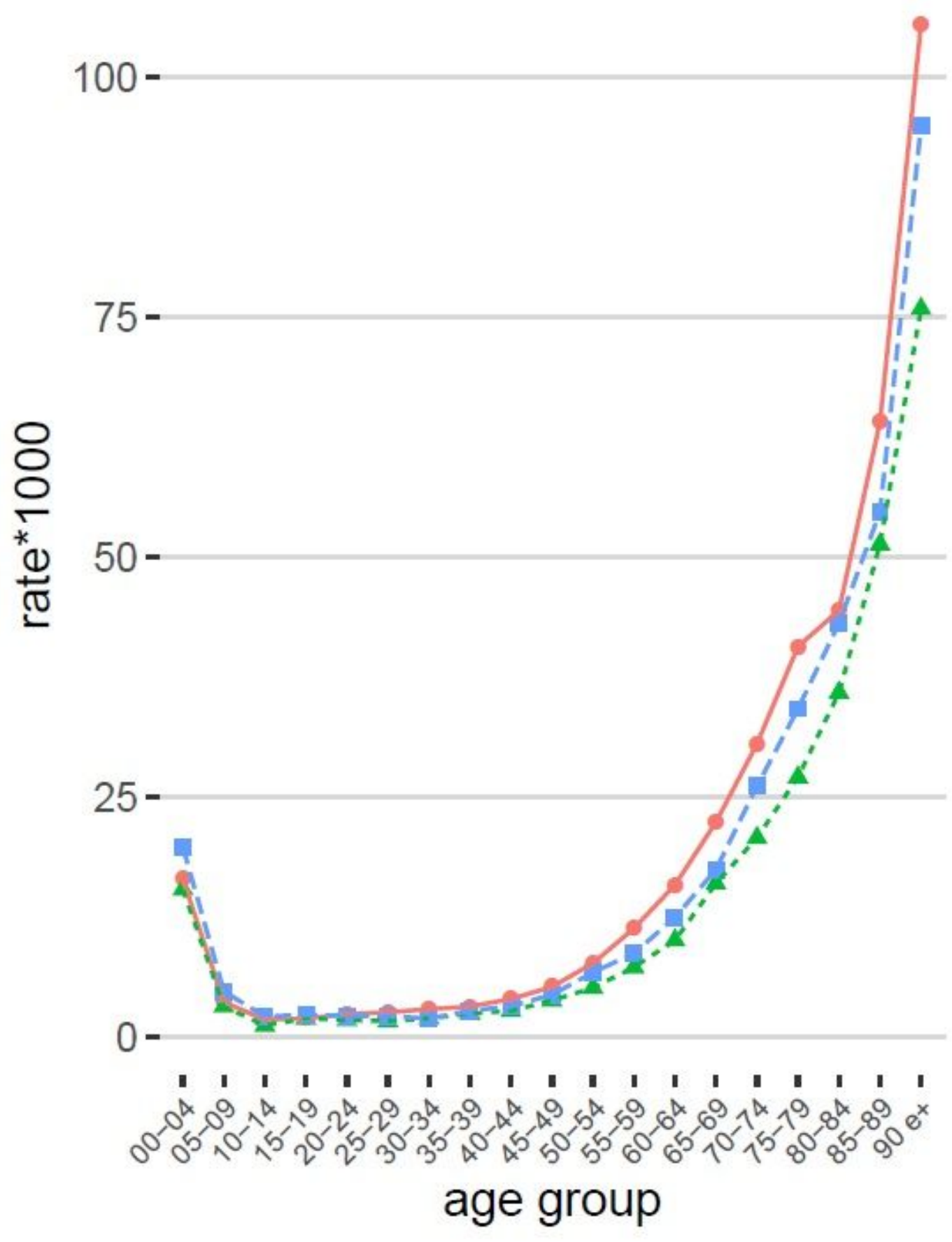

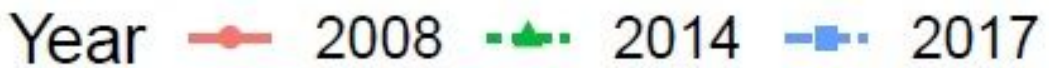

\section{Figure 3}

Distribution of hospitalizations for ambulatory care sensitive conditions rates per 1000 inhabitants, by age group in the years 2008, 2014 and 2017, in Sergipe. 


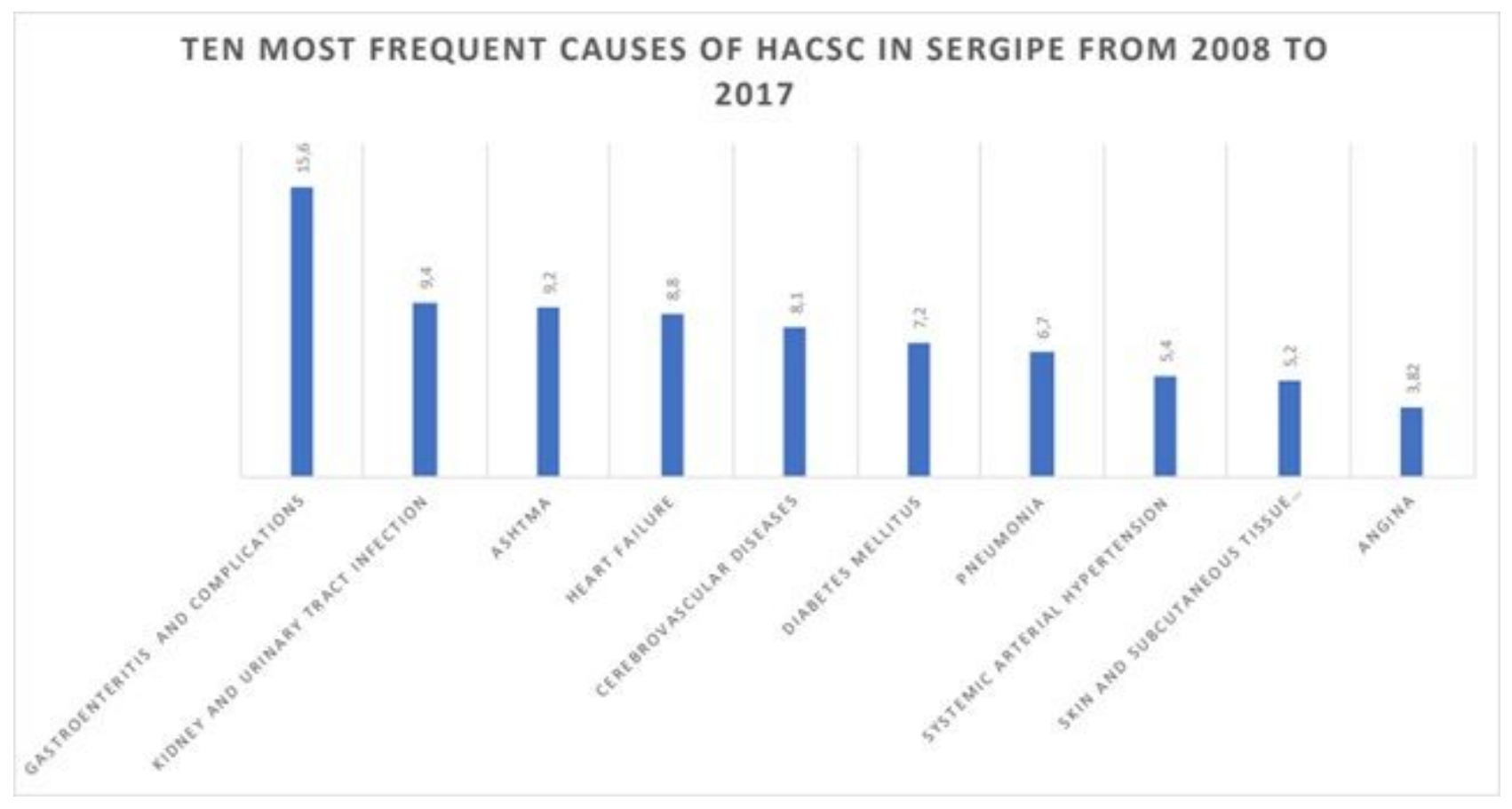

Figure 4

Distribution of the proportions of the ten most frequent causes of Hospitalizations for ambulatory care sensitive conditions in Sergipe from 2008 to 2017. 


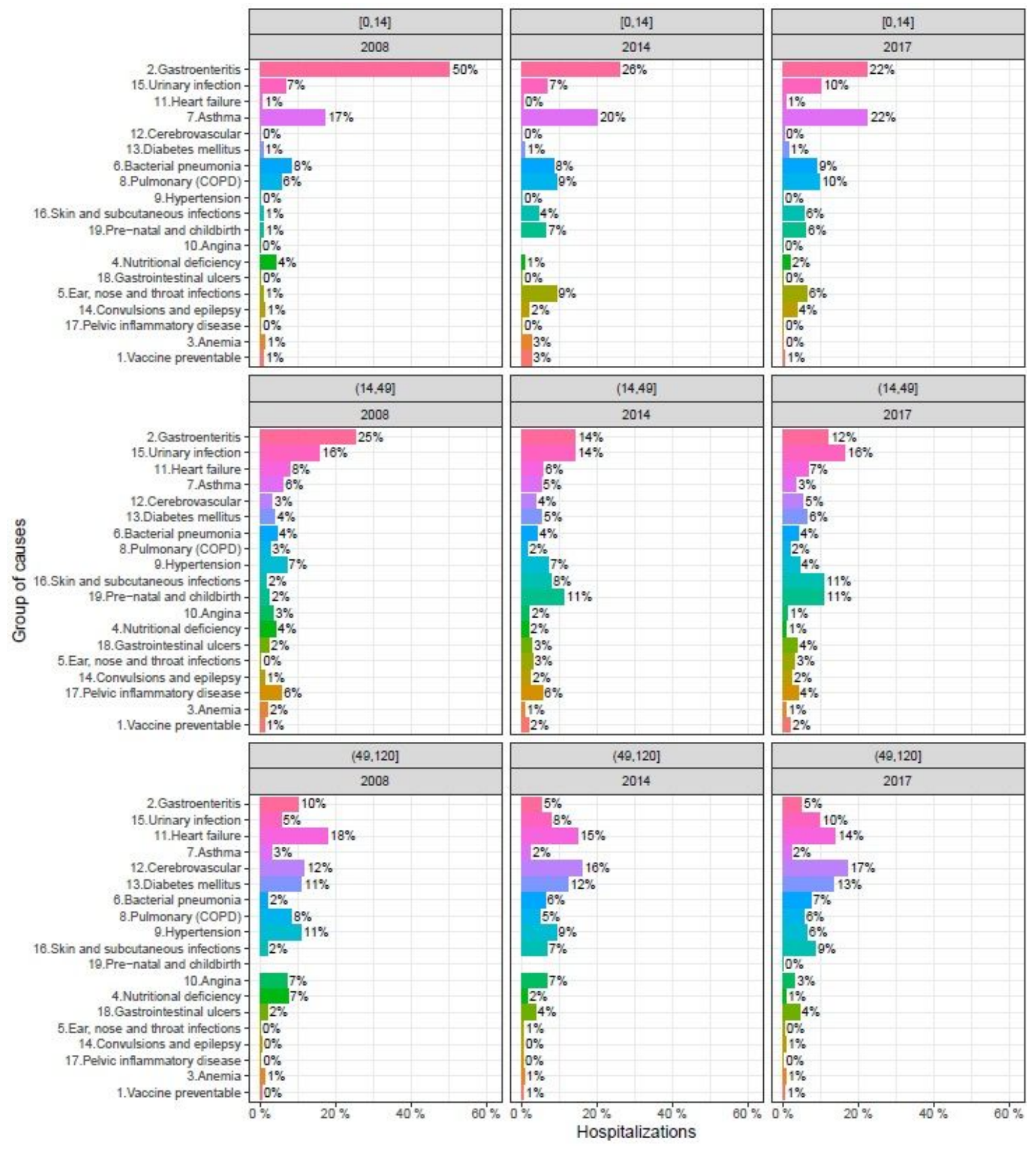

\section{Figure 5}

Distribution of Hospitalizations for ambulatory care sensitive conditions by group of causes and age group of 0-14 years, 15-49 years and 50-120 years in 2008, 2014 and 2017, in Sergipe. 